\title{
Pemanfaatan Limbah Padat Sari Apel sebagai Bahan Baku Cuka Apel Menggunakan Metode Backslop
}

\author{
Alvianty Novitasari ${ }^{1}$, Warkoyo ${ }^{1}$, Sri Winarsih ${ }^{\text {* }}$ \\ ${ }^{1}$ Program Studi Ilmu dan Teknologi Pangan, Fakultas Pertanian Peternakan Universitas \\ Muhammadiyah Malang, Malang, Indonesia \\ *Corresponding author email : sriwinarsih@umm.ac.id
}

\begin{abstract}
Solid wasted of apple cider containing a lot of compounds such as carbohydrates, glucose, malic acid, and flavonoids. The purpose of this research is to utilize solid wasted of apple cider as raw material of apple vinegar. The fermentation process of making apple vinegar in this research using backslop method.This research consists of 2 step of fermentation process. The first step of fermentation using yeast to transform sugar into alcohol. Second step fermentation is continuance of first step fermentation with addition of apple vinegar backslop culture which contain Acetobacter aceti with density $4 \times 107 c f u$ $1 \mathrm{ml}$ to transform alcohol to acetic acid. This research uses simple and factorial Randomized Block Design (RBD). Fermentation phase I using simple RBD with proportion of apple raw material (solid wasted of apple cider: apple) 100\%:0\%; 75\%: $25 \% ; 50 \%: 50 \% ; 25 \%: 75 \%$ as factor I. Fermentation phase II using factorial RBD with combination of factor I and addition of apple vinegar backslop with concentration 5\%, $10 \%$, and $15 \%$ as factor II.

The results showed that during the first step fermentation process the raw material proportion of apple (solid wasted of apple cider : apple) affected on total soluble solids, $p H$ value and alcohol content. Fermentation phase II showed interaction between proportion the raw material of apple (apple cider waste: apple) and the addition of backslop apple vinegar concentration to total dissolved solids, alcohol content, acetic acid, except $p H$ value. The best results showed treatment with apple material proportion (25\% solid wasted of apple cider : $75 \%$ apple) and addition of apple vinegar backslop concentration 15 $\%$ produce $4.6 \mathrm{~g} / 100 \mathrm{ml}$ acetic acid, 4\% soluble solids total, $\mathrm{pH}$ value of 3.4 and alcohol residue of $0 \%(\mathrm{~V} / \mathrm{V})$, with colorful organoleptic results quite appealing, the scent is sufficient, and preferences are favored by the panelists.
\end{abstract}

Keywords:Apple, apple vinegar, backslop, fermentation, solid waste

\section{PENDAHULUAN}

Buah apel merupakan buah yang mudah tumbuh di daerah beriklim tropis seperti di Indonesia. Salah satu kota penghasil buah apel adalah kota Batu, Malang. Buah Apel banyak diolah menjadi berbagai produk olahan seperti sari apel, dodol apel, keripik, jenang, dan olahan lainya. Berbagai olahan dari buah apel tentunya akan menghasilkan produk sampingan seperti kulit apel dan ampas apel yang belum banyak dimanfaatkan. Menurut Achmad dan Subagyo (2010) buangan dari proses olahan apel selama ini hanya digunakan sebagai 
substitusi pakan ternak dan pemupukan tanaman, padahal buangan olahan apel masih mengandung banyak kandungan seperti pektin, karbohidrat, asam asam organik seperti asam malat dan senyawa antioksidan seperti flavonoid yang masih bisa dimaanfaatkan. Menurut Keputusan Menteri Pertanian 893/Kpts/TP.240 (1984) buah apel mengandung kadar asam malat : 0,956 /100 g. Dalam 100 g ampas apel terkandung pektin sebesar 15-20\% dan sisanya merupakan serat pangan (Saparianti dkk., 2009). Apel memiliki antioksidan yang lebih penting yaitu senyawaan flavonoid. Kandungan senyawaan fenolik utama pada apel segar adalah quersetin glikosida, prosianidin B2, asam klorogenat, epikatekin, dan floretin glikosida terdapat melimpah pada kulit apel (Pietta, 2000).

Salah satu perusahaan pengolahan sari apel di kota Batu adalah KSU Brosem. Limbah padat sari apel yang dihasilkan KSU Brosem tidak mengalami proses pengolahan lanjutan dan biasanya diambil peternak sekitar sebagai pakan ternak. Menurut Saprianti dkk (2009) pada setiap kali produksi sari apel di UKM Brosem dapat dihasilkan 100\% ampas apel dari bahan baku apel yang digunakan. Ampas apel yang dimaksud berupa potongan buah apel yang telah diambil sarinya, bahannya masih berupa potongan buah apel utuh namun teksturnya lebih lunak. Bila rata-rata satu hari dihasilkan $10 \mathrm{~kg}$ ampas, maka selama enam hari kerja dapat mencapai $60 \mathrm{~kg}$ ampas yang terbuang. Kondisi ampas apel tersebut masih sangat baik dan dapat diproses lebih lanjut. Limbah ampas apel memiliki beberapa senyawa yang tersisa seperti kandungan serat pangan, karbohidrat dan glukosa. Beberapa senyawa yang tersisa dalam limbah ampas apel memiliki potensi untuk dikembangkan sebagai bahan baku pembuatan cuka apel. Cuka apel merupakan salah satu produk olahan fermentasi buah apel yang telah banyak dikenal oleh masyarakat Indonesia. Menurut Zubaidah (2011) cuka apel merupakan hasil fermentasi karbohidrat, Cuka apel mengandung senyawa antioksidan alami berupa senyawa flavonoid dan satu - satunya buah yang memiliki kandungan asam malat yang dapat membantu menetralkan radikal bebas hasil proses oksidasi dalam tubuh serta menanggulangi penyakit degeneratif.

Limbah apel memiliki beberapa kandungan seperti polisakarida, karbohidrat, pektin, asam malat dan senyawa antioksidan golongan flavonoid yang dapat dimanfaatkan sebagai bahan baku cuka apel menggunakan metode backslop dengan beberapa perlakuan tertentu. Ragam produk fermentasi tergantung pada kandungan substrat seperti air dan karbohidrat (Caturyanti, 2008). Kualitas cuka apel yang baik tergantung pada bahan baku yang digunakan serta metode yang diterapkan selama proses pembuatanya. Bahan baku merupakan sumber utama karbohidrat, glukosa, dan asam organik yang akan mempengaruhi kualitas cuka apel yang dihasilkan. Proses pembuatan cuka 
apel terdiri dari 2 tahapan yakni ketika glukosa diubah menjadi alkohol oleh bakteri Sacharomycess cereviceae dan tahap selanjutnya yakni pengubahan alkohol menjadi asam asetat oleh bakteri Acetobacter aceti secara aerob, cuka paling sedikit mengandung $4 \%$ asam asetat (Zubaidah, 2011). Menurut hasil penelitian Rahayu (2015) pembuatan cuka salak dengan perbedaan Acetobacter aceti yang berbeda (5\%, $10 \%$, dan $15 \%$ ) menunjukan pengaruh kadar asam asetat yang dihasilkan pada cuka salak. Semakin banyak inkulum yang ditambahkan maka semakin baik kualitas cuka salak yang dihasilkan. Perbedaan proporsi bahan baku buah apel (buah apel : ampas limbah ampas apel) dan perbedaan konsentrasi backslop cuka apel dianggap memiliki pengaruh terhadap kualitas cuka apel yang dihasilkan. Adapun tujuan dari penelitian untuk memanfaatkan limbah padat sari apel sebagai bahan baku cuka apel dan Mengetahui pengaruh interaksi proporsi bahan baku apel (limbah apel : buah apel) dan konsentrasi backslop cuka apel terhadap kualitas cuka apel.

\section{METODE PENELITIAN}

Bahan

Bahan yang diperlukan pada penelitian ini adalah limbah padat sari apel yang diperoleh dari Koperasi Serba Usaha Bromo Semeru "KSU" Kota Batu yang berupa ampas buah apel, buah apel Rome beauty, ragi atau soft instant, gula, air, dan cuka apel.

Alat

Peralatan yang dipergunakan penelitian ini meliputi autoclave all American B0004136, colony counter galaxy 230, inkubator medcenter einrichtungen GmbH, LAF crisbow dan pHmeter penty pH-009 (I) A.

\section{Pembuatan Cuka Apel}

Pembuatan cuka apel diawali dengan pencucian bahan baku buah apel dan limbah apel untuk menghilangkan kotoran. Bahan baku ditimbang sebanyak 50 g menggunakan timbangan analitik. Kemudian ditambahkan air $100 \mathrm{ml}$ dan dihaluskan bahan baku menggunakan blender dengan kecepatan sedang (speed 2). Filtrat apel disaring menggunakan saringan dan ditambahkan gula pasir $10 \%$. Filtrat apel di sterilisasi menggunakan autoclave dengan suhu $121^{\mathrm{O}} \mathrm{C}$ selama 15 menit. Ragi roti / soft instant $1 \% \mathrm{~b} / \mathrm{v}$ ditambahkan pada filtrat apel. Filtrat apel dilakukan fermentasi selama 2 minggu untuk fermentasi tahap I . Kemudian ditambahkan backslop cuka apel dengan kepadatan Acetobacter aceti 40 x $106 \mathrm{cfu} / \mathrm{ml}$ sebanyak $5 \%(\mathrm{v} / \mathrm{v}) ; 10 \%(\mathrm{v} / \mathrm{v}) ; 15 \%(\mathrm{v} / \mathrm{v})$ pada proses fermentasi tahap II selama 1 minggu.

\section{Parameter Penelitian}

Parameter yang diujikan pada penelitian ini adalah analisis $\mathrm{pH}$, analisis total asam tertitrasi, analisis total padatan terlarut, analisis kadar alkohol, TPC 
pada backslop cuka apel, serta analisis organoleptik warna, aroma dan kesukaan.

\section{Rancangan Percobaan dan Analisa Data}

Penelitian ini menggunakan 2 tahapan fermentasi yaitu fermentasi tahap I dan fermentasi tahap II. Fermentasi tahap I menggunakan Rancangan Acak (RAK) sederhana dengan 1 faktor. Faktor I adalah perbedaan proporsi bahan baku apel (limbah sari apel : buah apel) yang terdiri dari 4 perlakuan (100\%:0\%; 75\%:25\%; 50\%:50\%; 25\%:75\%) dan 5 kali ulangan.Setelah fermentasi tahap I dilanjutkan pada tahap fermentasi tahap II dengan penambahan Backslop cuka Apel sebagai Faktor II. Fermentasi tahap II menggunakan Rancangan Acak Kelompok (RAK) Faktorial dengan faktor I adalah proporsi bahan baku apel (limbah sari apel : buah apel) dan faktor 2 adalah penambahan konsentrasi backslop cuka apel $(5,10,15 \%)$ dan diperoleh 12 kombinasi dan 3 kali ulangan.

Data yang diperoleh dianalisa dengan sidik ragam anova (anova). Analisis of Variance atau ANOVA merupakan salah satu uji parametik yang berfungsi untuk membedakan nilai rata - rata lebih dari dua kelompok data tengah dengan cara membadingkan variansinya. Teknik analisa sidik ragam dapat digunakan untuk menguji kesamaan beberapa nilai tengah secara sekaligus dan dilakukan uji lanjut DMRT (Duncan Multiple Range Test).

\section{HASIL DAN PEMBAHASAN}

\section{Analisis Bahan Baku}

Bahan baku yang digunakan dalam pembuatan cuka apel yaitu limbah sari apel yang diperoleh dari KSU Brosem dan buah apel Rome beauty yang diperoleh dari toko buah di kota Batu. Pada Tabel 1 disajikan kandungan buah apel Rome beauty dan filtrat limbah sari apel.Buah apel Rome beauty memiliki kadar asam yang lebih tinggi yakni 10,6 g/100 ml jika dibandingkan limbah sari apel yakni 4,2 g/100 ml. Kadar asam limbah sari apel yang rendah diakibatkan terjadinya penurunan kadar asam setelah buah apel mengalami proses pemanasan atau perebusan sebelum akhirnya dibuang menjadi limbah. Menurut Meikapasa dan Sentivelova (2016) proses pemanasan pada buah dan sayur akan menurunkan kandungan asam - asam organik pada buah dan sayur sebanyak $50 \%$ karena asam - asam organik mudah larut oleh air dan struktur kimianya akan rusak akibat pemanasan. 
Tabel 1. Hasil Analisa Kandungan Buah Apel Rome beauty dan Filtrat Limbah Sari Apel

\begin{tabular}{llll}
\hline Komponen & $\begin{array}{l}\text { Buah Apel } \\
\text { beauty* }^{*}\end{array}$ & $\begin{array}{l}\text { Rome } \\
\text { Filtrat Limbah Sari } \\
\text { Apel }\end{array}$ \\
\hline Kadar Asam (g/100 ml) & 10,6 & 2,7 \\
Total Padatan (oBrix) & 12,2 & 11,5 \\
$\mathrm{pH}$ & 3,3 & 4 \\
\hline
\end{tabular}

Keterangan : * Sumber : Susanto dkk., (2011)

Total padatan terlarut buah apel Rome beauty memiliki nilai yang lebih tinggi yakni 12,2 obrix jika dibandingkan dengan total padatan terlarut limbah sari apel yakni 11,50brix. Brix manunjukan kandungan gula yang terdapat pada bahan, semakin besar nilai brix maka semakin banyak pula kandungan gula pada bahan pangan (Meikapasa dan Seventilova, 2016). Padatan terlarut menunjukan adanya kandungan gula pada bahan, pada buah apel Rome beauty menunjukkan kandungan padatan terlarut yang lebih tinggi dibandingkan dengan limbah apel. Hal ini dikarenakan sebagaian kadar gula dalam limbah sari apel telah telah larut selama proses perebusan, namun pada ampas buah yang tersisa dalam limbah sari apel masih memiliki kandungan polisakarida seperti fruktosa yaitu 7 brix.

Nilai $\mathrm{pH}$ buah apel Rome beauty lebih rendah yakni 3,3 jika dibandingkan dengan nilai $\mathrm{pH}$ limbah sari apel yakni 4. Perbedaan nilai $\mathrm{pH}$ diakibatkan oleh perbedaan kandungan asam kedua bahan baku. Kadar asam yang tinggi pada bahan akan memberikan nilai $\mathrm{pH}$ yang rendah pada filtrat. Limbah sari apel memiliki $\mathrm{pH}$ yang tidak terlalu tinggi apabila dibandingkan dengan $\mathrm{pH}$ buah apel Rome beauty. Buah apel Rome beauty mengandung asam - asam organik seperti asam malat dan asam sitrat yang lebih tinggi bila dibandingkan limbah sari apel, selain itu limbah sari apel mengalami proses pemanasan sehingga asam - asam organik akan hilang dan menurunkan nilai $\mathrm{pH}$. Menurut Rahayu (2015) kecenderungan kenaikan $\mathrm{pH}$ produk dengan semakin lamanya pemanasan disebabkan pengaruh panas yang diberikan dapat mengakibatkan kehilangan beberapa zat gizi terutama zat-zat yang labil terhadap panas seperti asam-asam organik, salah satunya asam sitrat, asam askorbat serta asam malat lain sehingga meningkatkan nilai $\mathrm{pH}$.

Filtrat limbah sari apel memiliki beberapa kandungan yang tersisa seperti asam - asam organik $2,7 \mathrm{~g} / 100 \mathrm{ml}$ dan gula 11,5 brix yang dapat dimanfaatkan sebagai bahan baku cuka apel. Untuk menghasilkan cuka apel yang berkualitas sesuai SNI dibutuhkan beberapa perlakuan dalam pengolahan cuka apel. 
Menurut Zubaidah (2011) bahan baku merupakan sumber utama karbohidrat, glukosa, dan asam organik yang akan mempengaruhi kualitas cuka apel yang dihasilkan.

\section{Analisis Backslop Cuka Apel}

Tabel 2 menunjukan backslop cuka apel yang digunakan dalam fermentasi cuka apel mengandung Acetobacter aceti sebanyak 40 x $106 \mathrm{cfu} / \mathrm{ml}$. Bakteri Acetobacter aceti dalam backslop cuka apel berperan penting dalam perombakan alkohol menjadi asam asetat pada fermentasi tahap II minggu ke 3. Menurut Desrosier (2008) cuka dibuat melalui 2 tahapan fermentasi. Pertama, fermentasi alkohol yaitu glukosa diubah menjadi alkohol oleh Saccharomyces cereviceae secara anaerob. Kedua, yaitu fermentasi asam asetat oleh Acetobacter aceti yang akan mengoksidasi alkohol menjadi asam asetat secara aerob. Kedua fermentasi tersebut biasanya dilakukan secara terpisah.

Tabel 2. Kandungan Backslop Cuka Apel

\begin{tabular}{ll}
\hline \multicolumn{1}{c}{ Komponen } & Backslop cuka Apel \\
\hline Acetobacter aceti $(\mathrm{kol} / \mathrm{ml})$ & $40 \times 10^{6}$ \\
$\mathrm{pH}$ & 3,1 \\
\hline
\end{tabular}

Nilai pH backslop cuka apel memiliki nilai yang rendah karena kandungan asam pada cuka apel. Kandungan asam dan $\mathrm{pH}$ yang rendah pada suatu produk pangan memungkinkan tumbuhnya bakteri - bakteri yang tahan pada kondisi asam. Menurut Ray dan Bhunia (2008) setiap organisme memiliki kadar $\mathrm{pH}$ tertentu untuk tumbuh optimal. Ketika $\mathrm{pH}$ mengalami penurunan melebihi batas optimum suatu mikroorganisme, maka mikroorganisme tersebut tidak hanya berhenti untuk tumbuh, namun juga kehilangan viabilitasnya.

\section{Cuka Apel Tahap I}

Pada proses fermentasi tahap I dalam pembuatan cuka apel gula akan dirombak oleh Sacharomycess cereviceae menjadi alkohol. Fermentasi tahap I berlangsung selama 2 minggu mulai dari minggu ke-0 hingga minggu ke-2. Analisa filtrat cuka apel pada fermentasi tahap I meliputi total padatan terlarut, $\mathrm{pH}$, dan kadar alcohol (Tabel 3). 
Tabel 3. Rerata Kadar Total Padatan Terlarut (TPT), pH dan Alcohol Filtrat Cuka Apel FermentasiTahap I

\begin{tabular}{lccrrc}
\hline Proporsi bahan & \multicolumn{2}{c}{ TPT (Brix) } & \multicolumn{2}{c}{$\mathrm{pH}$} & Alkohol \\
\cline { 2 - 6 } & $\mathrm{Ke}^{-} 0$ & $\mathrm{Ke}^{-} 2$ & $\mathrm{Ke}^{-} 0$ & $\mathrm{Ke}^{-} 2$ & $\mathrm{Ke}^{-0}$ \\
\hline L0 (100\%:0\%) & $11,5 \mathrm{a}$ & $3,16 \mathrm{a}$ & $5,4 \mathrm{~d}$ & $4,7 \mathrm{~d}$ & $0,91 \mathrm{~b}$ \\
L1 $(75 \%: 25 \%)$ & $11,9 \mathrm{ab}$ & $3,78 \mathrm{~b}$ & $5,1 \mathrm{c}$ & $4,6 \mathrm{c}$ & $0,90 \mathrm{~b}$ \\
L2 ( $50 \%: 50 \%)$ & $12,0 \mathrm{~b}$ & $3,94 \mathrm{c}$ & $5,0 \mathrm{~b}$ & $4,2 \mathrm{~b}$ & $0,62 \mathrm{a}$ \\
L3 $(25 \%: 75 \%)$ & $12,1 \mathrm{~b}$ & $3,98 \mathrm{c}$ & $4,8 \mathrm{a}$ & $4,0 \mathrm{a}$ & $0,64 \mathrm{a}$
\end{tabular}

Keterangan: Angka - angka yang diikuti huruf yang sama menunjukan tidak berbeda nyata menurut uji duncan pada taraf $5 \%$.

Kadar total padatan terlarut filtrat cuka apel selama proses fermentasi tahap 1 mengalami penurunan dari minggu ke-0 hingga minggu ke-2. Tren penurunan total padatan terlarut filtrat cuka apel selama fermentasi tahap I dapat dilihat pada Gambar 1. Total padatan terlarut tertinggi terdapat pada perlakuan L3 dengan proporsi bahan baku apel menggunakan $25 \%$ limbah sari apel dan $75 \%$ buah apel. Sedangkan total padatan terlarut terendah terdapat pada perlakuan L0 dengan proporsi bahan baku apel $100 \%$ limbah sari apel dan $0 \%$ buah apel. Kadar total padatan terlarut pada perlakuan L3 lebih besar daripada perlakuan L0 diakibatkan oleh proporsi bahan baku yang digunakan. Semakin banyak proporsi buah apel yang digunakan maka semakin tinggi total padatan terlarut dalam bahan, sedangkan semakin banyak proporsi limbah sari apel yang digunakan maka kadar total padatan terlarut semakin menurun. Menurut Susanto dkk., (2011) buah apel memiliki kadar sukrosa 12,1 persen brix. Limbah sari apel mengalami proses perebusan yang akan menurunkan kadar glukosa dalam ampas apel sehingga memperngaruhi kadar total padatan terlarut. Menurut Meikapasa dan Senventilova (2016) proses perebusan pada bahan meggunakan air sebagai media penghantar panas akan menurunkan kandungan nutrisi pada bahan seperti vitamin, karbohidrat, dan asam - asam organik lainya. Penurunan kadar total padatan terlarut dari mula - mula pada minggu ke-0 hingga minggu ke-2 selama fermentasi tahap I terjadi karena perombakan glukosa oleh Sacharomycess cereviceae menjadi alkohol dan CO2. Penurunan total padatan terlarut ditandai dengan menurunya derajat brix pada bahan. Menurut Elevri (2006) derajat brix menunjukan persen sukrosa yang terkandung dalam bahan. Pada proses fermentasi sukrosa inilah yang akan diubah menjadi alkohol. Total padatan terlarut filtrat cuka apel selama fermentasi tahap I mengalami penurunan sukrosa sebanyak 7-8\%. Penurunan kadar total padatan terlarut menunjukan keberhasilan fermentasi tahap I oleh 
Sacharomycess cereviceae akibat konsumsi glukosa. Sacharomycess cereviceae memiliki enzim invertase yang bekerja spesifik mengubah glukosa menjadi alkohol dan, selain enzim invertasi Sacharomycess cereviceae memiliki enzim zimase yang mengubah glukosa menjadi CO2. Menurut Caturyanti, dkk (2008) jumlah yeast yang ditambahkan pada cider berpengaruh terhadap kadar gula selama proses fermentasi. Yeast mampu mengkonsumsi gula sebanyak 7\% pada fermentasi glukosa sehingga menurunkan total padatan terlarut.

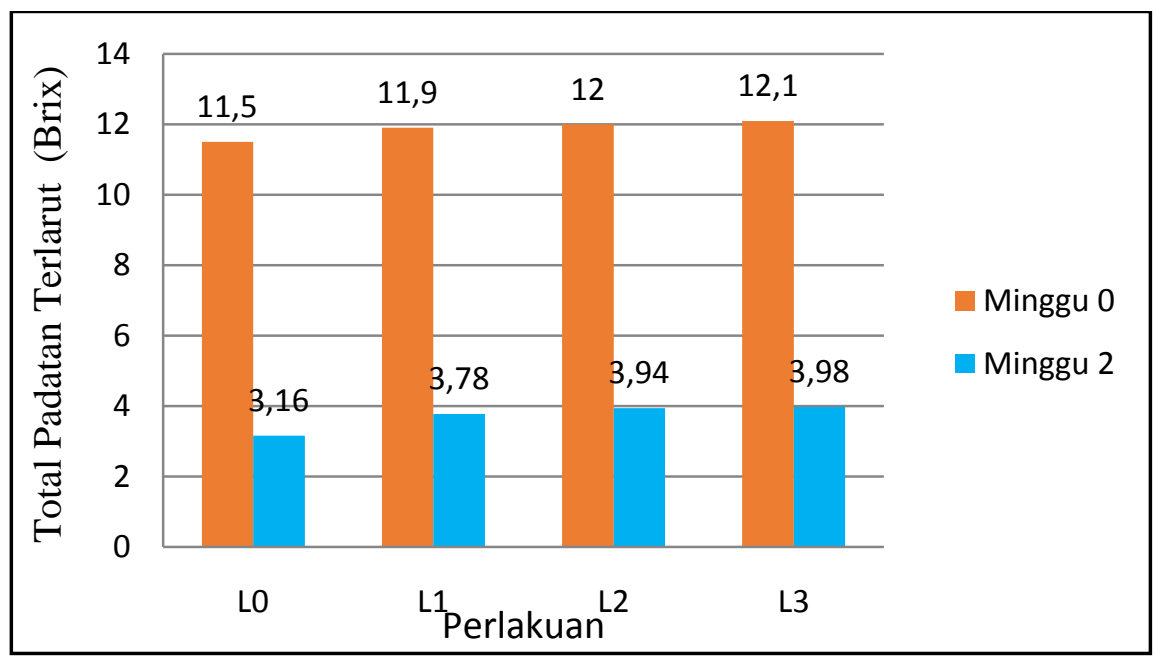

Gambar 1. Tren Total Padatan Terlarut Cuka Apel Fermentasi Tahap I

Nilai $\mathrm{pH}$ cuka apel selama proses fermentasi tahap I mengalami penurunan dari minggu ke-0 hingga minggu ke-2. Tren penurunan nilai $\mathrm{pH}$ filtrat cuka apel selama fermentasi tahap I dapat dilihat pada Gambar 2. Hasil uji Anova pH cuka apel fermentasi tahap I menunjukan terjadi proporsi bahan baku (limbah apel : buah apel) berpengaruh terhadap nilai pH filtrat cuka apel. Nilai rerata $\mathrm{pH}$ filtrat cuka apel fermentasi tahap I dapat dilihat pada Tabel 9. Nilai $\mathrm{pH}$ filtrat cuka apel selama selama fermentasi tahap I mengalami penurunan dari minggu ke-0 hingga minggu ke-2. Nilai $\mathrm{pH}$ terendah terdapat pada perlakuan L3 dengan proporsi bahan baku apel menggunakan $25 \%$ limbah sari apel dan $75 \%$ buah apel, sedangkan nilai pH tertinggi terdapat pada perlakuan L0 dengan proporsi bahan baku apel menggunakan $100 \%$ limbah sari apel dan $0 \%$ buah apel. Nilai $\mathrm{pH}$ yang rendah menunjukan kandungan asam pada bahan, semakin rendah $\mathrm{pH}$ filtrat cuka apel maka semakin banyak kandungan asam di dalamnya. Proporsi buah apel yang lebih banyak akan menurunkan $\mathrm{pH}$ cuka apel karena buah apel memiliki kandungan asam - asam organik seperti asam sitrat dan asam malat yang lebih banyak dibandingkan limbah sari apel. Menurut Widyastuti, dkk (1993) apel Rome beauty memiliki pH sekitar 3,46 dengan kandungan asam asetat sekitar 0,35mg serta vit C 7,39 mg per 100 gram.Penurunan nilai pH juga disebabkan mulai terbentuknya alkohol yang bersifat asam selama fermentasi tahap I. Menurut Ray dan Bhunia (2008) 
alkohol merupakan asam lemah. Menurut Elevri (2006) nilai $\mathrm{pH}$ optimum yang digunakan oleh yeast dalam memecah alkohol adalah 4,5-5. Berdasarkan nilai pH cuka apel fermentasi tahap I menunjukan rerata nilai $\mathrm{pH}$ 4,8 - 5 sehingga pH yang dihasilkan masih sesuai untuk pertumbuhan yeast.

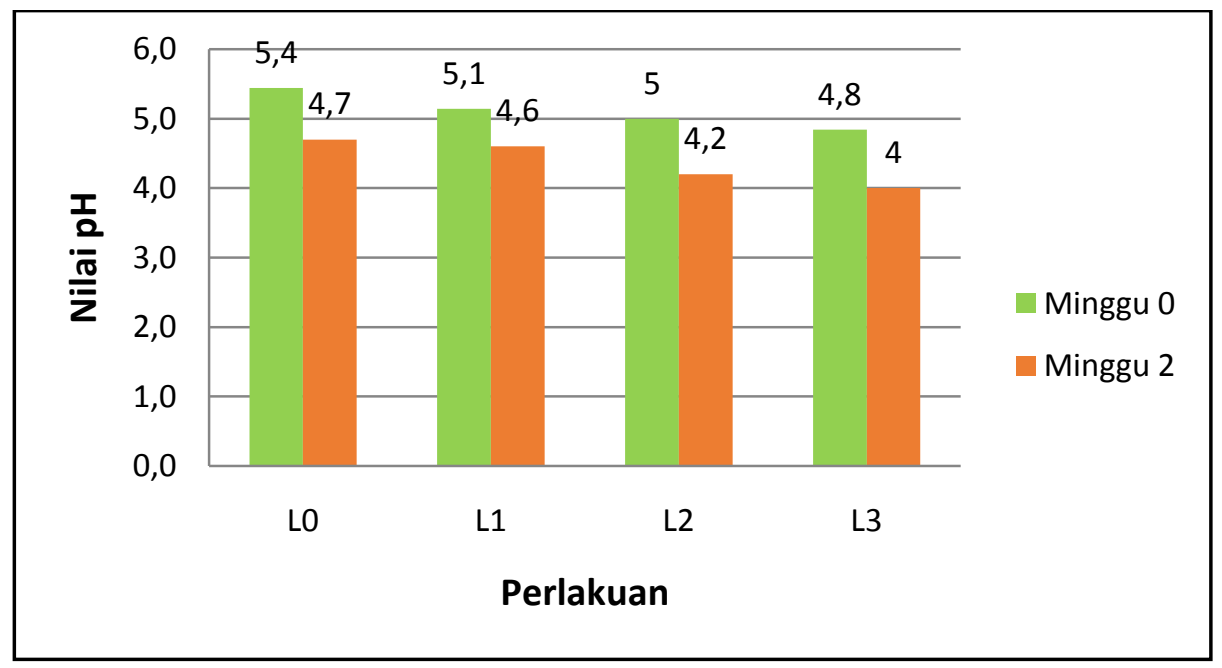

Gambar 2. Tren Nilai pH Cuka Apel Fermentasi Tahap I

Kadar alkohol pada cuka apel mulai terbentuk pada minggu ke-2 selama proses fermentasi tahap I. Tren kadar alkohol yang mulai terbentuk pada fermentasi tahap I dapat dilihat pada Gambar 3.Hasil uji Anova kadar alkohol cuka apel fermentasi tahap I menunjukan proporsi bahan baku (limbah apel : buah apel) berpengaruh terhadap kadar alkohol. Nilai rerata kadar Alkohol filtrat cuka apel fermentasi tahap I dapat dilihat pada Tabel 3. Kadar alkohol tertinggi terdapat pada perlakuan L0 dengan proporsi bahan baku apel menggunakan 100 \% limbah sari Apel. Kadar alkohol pada proses fermentasi tahap I dipengaruhi oleh kadar glukosa yang dirombak oleh Sacharomycess cereviceae menjadi alkohol dan karbondioksida. Selain dipengaruhi oleh substrat kadar alkohol yang terbentuk juga dipengaruhi oleh $\mathrm{pH}$ lingkungan. Pada perlakuan L0 gula yang dirombak oleh yeast lebih besar dibandingkan dengan perlakuan lainya yakni sekitar 9,34 brix dengan pH lingkungan yang optimum pH 4,7. Kadar alkohol cuka apel selama fermentasi tahap I mengahasilkan kadar alkohol yang lebih sedikit apabila dibandingkan dengan beberapa literatur. Menurut Caturyanti (2008) kadar alkohol pada cider selama 7 hari menghasilkan 3,9 \% alkohol, sedangkan menurut Ma'sum (2006) kadar alkohol yang dihasilkan oleh fermentasi cuka apel manalagi dengan waktu fermentasi 30 jam pada suhu ruang menghasilkan $0,5 \%$ alkohol. 


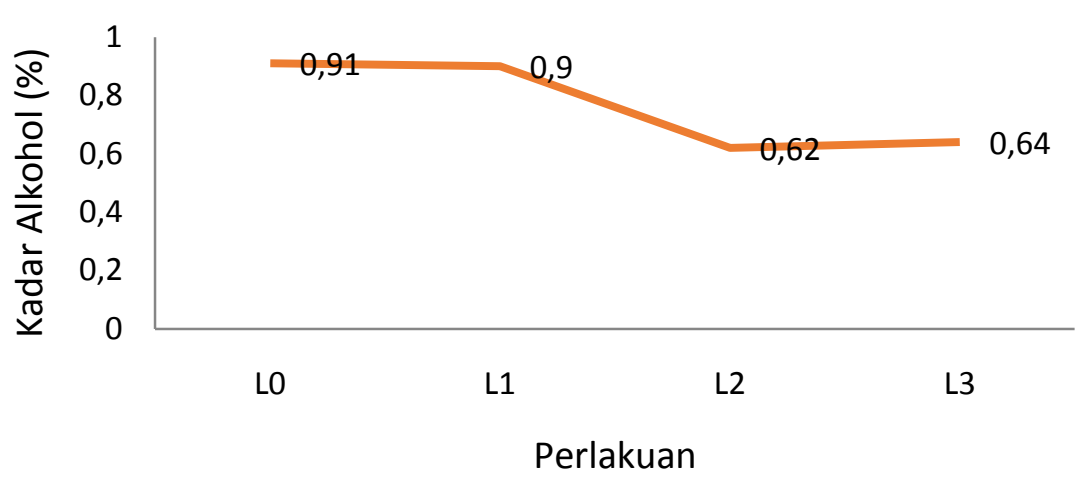

Gambar 3. Tren Kadar Alkohol Cuka Apel Fermentasi Tahap I

\section{Cuka Apel Tahap II}

Pada proses fermentasi tahap II dalam pembuatan cuka apel, alkohol yang dihasilkan selama proses fermentasi tahap I akan dirombak oleh Acetobacter aceti yang terdapat pada backslop cuka apel dengan kepadatan 40 x $106 \mathrm{cfu} / \mathrm{ml}$ menjadi asam asetat. Fermentasi tahap II berlangsung selama 1 minggu mulai dari minggu ke-2 hingga minggu ke-3. Analisa filtrat cuka apel fermentasi tahap II meliputi total padatan terlarut, pH, kadar alkohol, kadar asam asetat, serta uji organoleptik warna, aroma, dan kesukaan.

Hasil uji Anova menunjukan terdapat interaksi antara proporsi bahan baku cuka apel (limbah apel : buah apel) dan konsentrasi backslop cuka apel terhadap kadar total padatan terlarut cuka apel fermentasi tahap II. Rata rata kadar total padatan terlarut cuka apel pada fermentasi tahap II tidak jauh berbeda dari nilai total padatan terlarut fermentasi tahap I. Total padatan terlarut terendah terdapat pada perlakuan L0A2 dengan proporsi bahan baku apel (100\% limbah sari apel : 0 \% buah apel ) dan penambahan konsentrasi backslop cuka apel 10\%, sedangkan kadar total padatan terlarut terendah terdapat pada perlakuan L2A2 dengan proporsi bahan baku apel (50\% limbah sari apel : $50 \%$ buah apel) dan penambahan konsentrasi backslop cuka apel 10 \%. Perbedaan kadar total padatan terlarut pada fermentasi tahap II yang disebabkan oleh kondisi substrat fermentasi yang telah terombak sepenuhnya sehingga pada fermentasi tahap I bakteri mencapai fase stasioner dan tidak terjadi pengurangan jumlah glukosa. Sisa sukrosa yang masih terdapat pada filtrat cuka apel fermentasi tahap II juga diakibatkan oleh penambahan sukrosa pada awal bahan. Pada awal pembuatan cuka apel sukrosa yang ditambahkan sebesar 10 \% dianggap terlalu besar sehingga sel Sacharomycess cereviceae akan mengalami osmosis yang mengakibatkan dinding sel bakteri mengalami lisis sehingga terjadi kematian. Menurut Zubaidah (2011) pada pembuatan cuka buah biasa ditambahkan gula sebesar $10-16 \%$. Selain itu pada fermentasi tahap II telah terbentuk alkohol yang akan merubah kondisi lingkungan 
sehingga yeast tidak tumbuh dapat tumbuh optimal. Menurut (Okunowo dan Oluwanisula, 2007) aktivitas yeast tidak lagi optimal karena adanya alkohol pada wine. Pada fermentasi tahap II kadar total padatan terlarut masih sesuai dengan standart SNI (01-4371-1996) sisa gula total pada cuka apel min $1 \%$.

Tabel 4. Rerata Kadar Total Padatan Terlarut Cuka Apel Fermentasi Tahap II

\begin{tabular}{ll}
\hline Proporsi Bahan Baku & \multicolumn{1}{c}{ TPT (0Brix) } \\
\hline L0A1 $(100 \%: 0 \%-5 \%)$ & $3,37 \mathrm{ab}$ \\
L0A2 $(100 \%: 0 \%-10 \%)$ & $3,27 \mathrm{a}$ \\
L0A3 $(100 \%: 0 \%-15 \%)$ & $3,33 \mathrm{ab}$ \\
L1A1 $(75 \%: 25 \%-5 \%)$ & $3,87 \mathrm{~b}$ \\
L1A2 $(75 \%: 25 \%-10 \%)$ & $3,90 \mathrm{~b}$ \\
L1A3 $(75 \%: 25 \%-15 \%)$ & $3,90 \mathrm{~b}$ \\
L2A1 $(50 \%: 50 \%-5 \%)$ & $4,03 \mathrm{bc}$ \\
L2A2 $(50 \%: 50 \%-10 \%)$ & $4,10 \mathrm{c}$ \\
L2A3 $(50 \%: 50 \%-15 \%)$ & $3,90 \mathrm{~b}$ \\
L3A1 $(25 \%: 75 \%-5 \%)$ & $3,97 \mathrm{bc}$ \\
L3A2 $(25 \%: 75 \%-10 \%)$ & $3,97 \mathrm{bc}$ \\
L3A3 $(25 \%: 75 \%-15 \%)$ & $4,00 \mathrm{c}$
\end{tabular}

Keterangan : Angka - angka yang diikuti huruf yang sama menunjukan tidak berbeda nyata menurut uji duncan pada taraf $5 \%$.

Hasil uji Anova menunjukan tidak terdapat interaksi antara proporsi bahan baku (limbah apel: buah apel) dan konsentrasi backslop cuka apel terhadap nilai $\mathrm{pH}$ setelah fermentasi tahap II. Rerata nilai $\mathrm{pH}$ cuka apel fermentasi tahap II menunjukkan filtrat cuka apel yang terbentuk bersifat asam. Nilai $\mathrm{pH}$ fermentasi tahap II mengalami penurunan dari nilai $\mathrm{pH}$ fermentasi tahap I. Penurunan nilai $\mathrm{pH}$ diakibatkan mulai terbentuknya asam asetat pada fermentasi tahap II. Menurut Caturyanti (2008) nilai $\mathrm{pH}$ substrat pada akhir fermentasi berkaitan erat dengan produksi asam asetat, semakin besar asam asetat yang dihasilkan semakin turun nilai $\mathrm{pH}$ nya. Fermentasi pada cider apel menghasilkan $\mathrm{pH}$ sebesar 3,09. Hasil nilai $\mathrm{pH}$ yang tidak signifikan dipengurahi adanya asam organik lainnya di dalam cuka apel selain asam asetat yang terbentuk. Asam organik selain asam asetat yang terdapat pada filtrat cuka apel fermentasi tahap II, diakibatkan oleh buah apel yang digunakan sebagai bahan baku mengandung asam - asam organik seperti asam malat dan 
asam sitrat yang ikut mempengaruhi nilai $\mathrm{pH}$. Widyastuti, dkk (1993) apel Rome beauty mengandung vit $\mathrm{C}$ sebesar $7 \mathrm{mg} / 100 \mathrm{~g}$. Menurut Keputusan Menteri Pertanian 893/Kpts/TP.240 (1984) buah apel Rome beauty mengandung kadar asam malat : 0,956 /100 g.

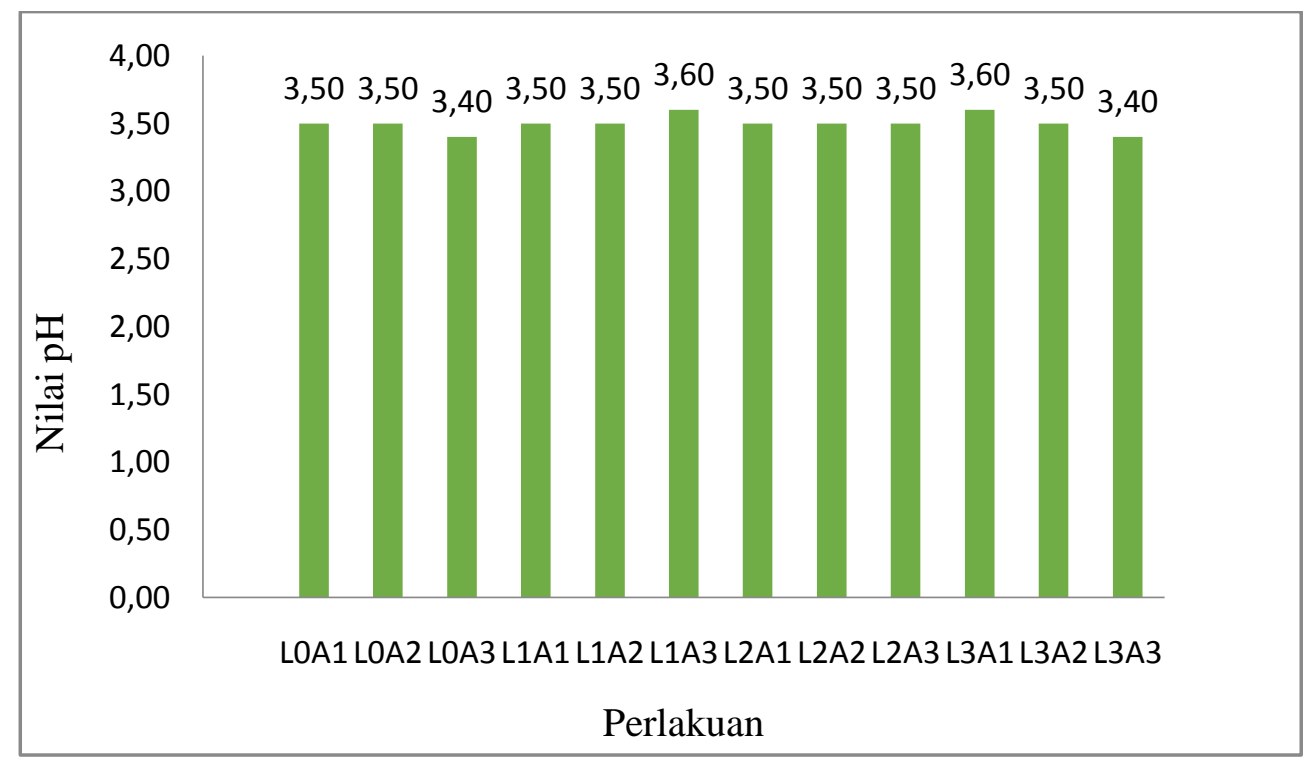

Gambar 4. Rerata Nilai pH Cuka Apel Fermentasi Tahap II

Hasil uji Anova kadar alkohol cuka apel fermentasi minggu ke II menunjukan tidak terjadi interasksi antara kombinasi perlakuan proporsi bahan baku apel (limbah sari apel: buah apel) dan konsentrasi backslop cuka apel. Kadar alkohol fermentasi tahap II dapat dilihat pada Gambar 7. Hasil menunjukan penambahan konsentrasi backslop cuka apel yang berbeda berpengaruh terhadap penurunan kadar alkohol selama fermentasi tahap II. Rerata menunjukan semakin banyak konsentrasi backslop cuka apel yang ditambahkan maka semakin rendah kadar alkohol. Pada fermentasi tahap II alkohol akan dirubah oleh Acetobacter aceti yang terdapat pada backslop cuka apel menjadi asam asetat sehingga menurunkan presentase kadar alkohol dalam cuka apel. Sisa alkohol terendah terdapat pada perlakuan A3 dengan penambahan konsentrasi backslop cuka apel sebesar $15 \%$.Backslop cuka apel mengandung bakteri asam asetat Acetobacter aceti sebanyak $40 \times 106 \mathrm{cfu} / \mathrm{ml}$ sehingga semakin banyak konsentrasi backslop cuka apel yang ditambahkan maka semakin banyak bakteri yang akan mengubah alkohol menjadi asam asetat dan menurunkan kadar alkohol pada fermentasi tahap II. Menurut Rahayu (2015) pemberian konsentrasi inokulum yang berbeda pada cuka salak menghasilkan kadar asam asetat yang berbeda. Berbagai variasi penambahan konsentrasi inokulum $5 \%, 10 \%$, dan $15 \%$ memberikan hasil optimum pada 
penambahan inokulum sebesar $15 \%$. Sisa kadar alkohol pada cuka apel fermentasi tahap II dengan perlakuan A1, A2, dan A3 telah memenuhi standart SNI. Menurut SNI 014371 (1996) kadar alkohol sisa pada cuka apel maks $1 \%$.

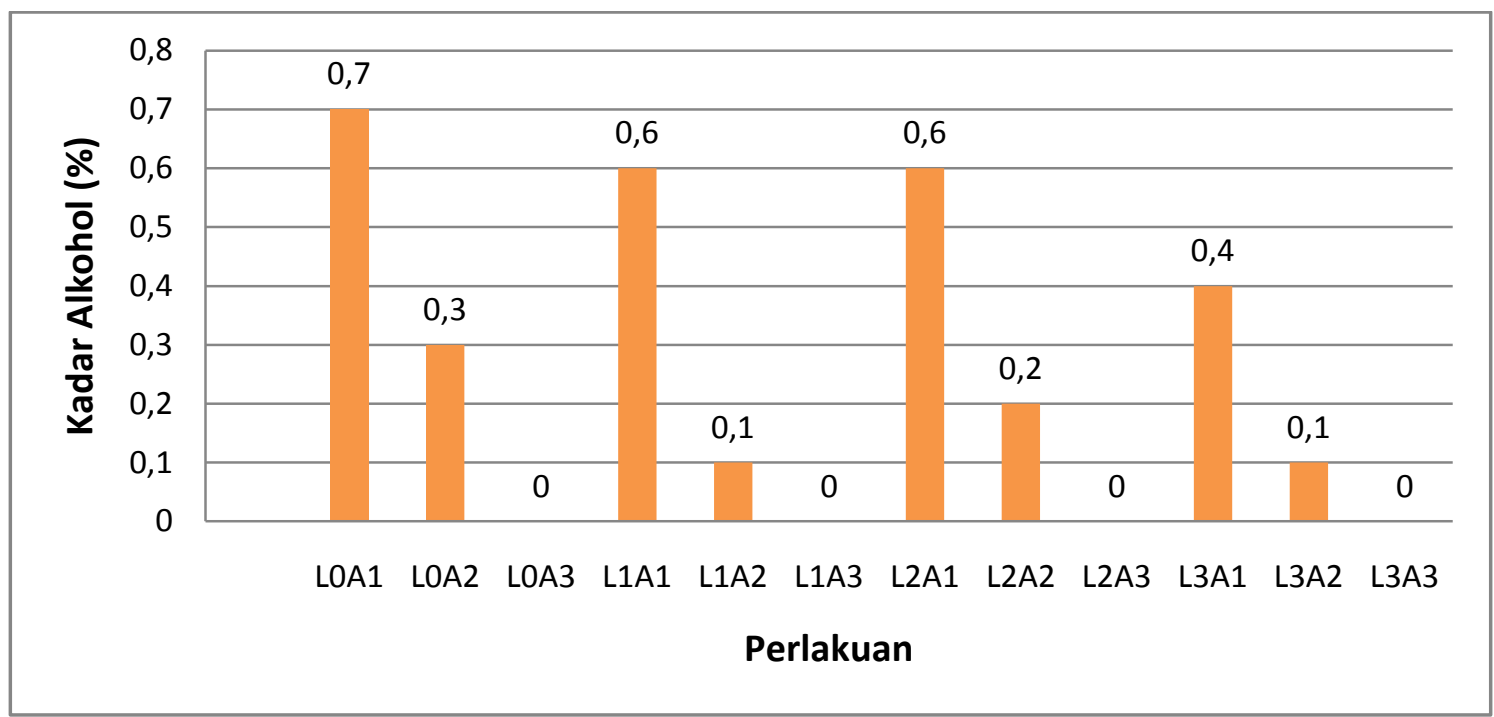

Gambar 5. Rerata Sisa Kadar AlkoholCuka Apel Fermentasi Tahap II

Hasil uji Anova kadar asam asetat cuka apel fermentasi tahap II menunjukan tidak terjadi interasksi antara kombinasi perlakuan proporsi bahan baku apel (limbah sari apel : buah apel) dan konsentrasi backslop cuka apel. Kadar asam asetat fermentasi tahap II dapat dilihat pada Gambar 6. Rerata menunjukan konsentrasi backslop cuka apel memberikan perbedaan yang nyata terhadap kadar asam asetat yang dihasilkan. Asam asetat adalah asam organik yang dihasilkan akibat perombakan alkohol oleh bakteri Acetobacter aceti. Kadar asam asetat tertinggi diperoleh pada perlakuan A3 dengan penambahan konsentrasi backslop cuka apel $15 \%$ menghasilkan rata - rata kadar asam asetat 3,95 g/100ml. Menurut (SNI 01-4371-1996) kadar asam asetat minimal untuk produk cuka apel adalah $4 \mathrm{~g} / 100 \mathrm{ml}$. Backslop cuka apel mengandung bakteri sebesar 40 x $106 \mathrm{Cfu} / \mathrm{ml}$ sehingga semakin banyak konsentrasi backslop cuka apel yang ditambahkan maka semakin banyak pula jumlah alkohol yang diubah menjadi asam asetat. Kadar asam asetat yang dihasilkan pada fermentasi tahap II pada penelitian kali ini lebih tinggi yaitu 3,95\% apabila dibandingkan dengan kadar asam asetat cuka apel hasil penelitian Caturyanti (2008) pada hasil fermentasi cuka apel menggunakan bahan baku apel Rome beauty menghasilkan kadar asam asetat sebesar $3,11 \%$. 


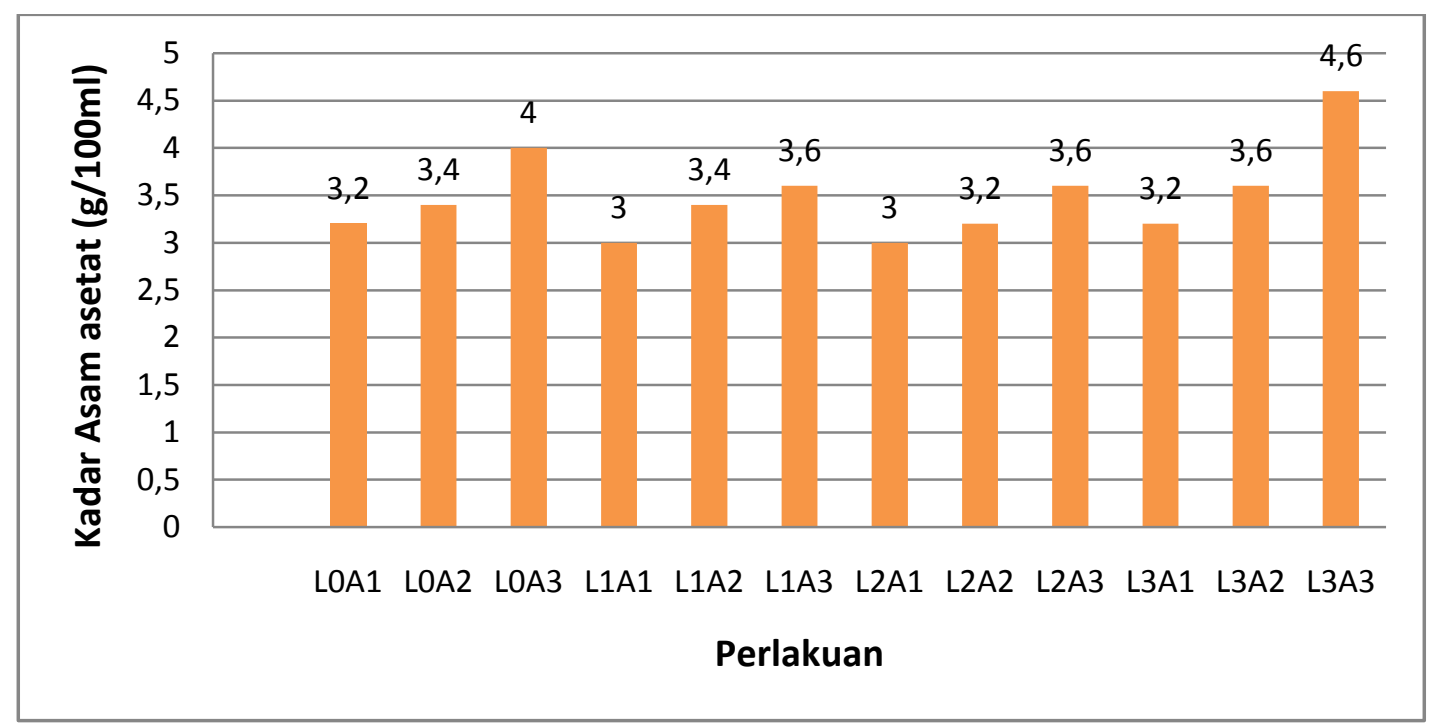

Gambar 6. Rerata Kadar Asam AsetatCuka Apel Fermentasi Tahap II

\section{Organoleptik Cuka Apel}

Analisa uji organoleptik dilakukan untuk mengetahui tingkat penerimaan konsumen terhadap produk cuka apel yang dihasilkan. Analisa uji organoleptik cuka apel meliputi warna, aroma, dan kesukaan. Menurut Carpenter (2000) Analisa uji organoleptik dilakukan untuk mengetahui parameter kesukaan konsumen terhadap produk pangan. Uji organoleptik dilakukan terhadap 25 panelis untuk menilai kualitas cuka apel berdasarkarn warna, aroma dan kesukaan.

Hasil uji menunjukan nilai skor uji organoleptik warna, aroma dan kesukaan cuka apel. Hasil uji Anova menunjukan perlakuan proporsi bahan baku apel dan konsentrasi backslop apel berpengaruh terhadap skor warna dan tidak berpengaruh terhadap skor aroma dan kesukaan. Warna cuka apel yang paling disukai panelis yaitu pada perlakuan L2A2 dengan perlakuan proporsi bahan baku apel (50\% limbah apel : $50 \%$ buah apel) dan penambahan konsentrasi backslop cuka apel $15 \%$. Warna sampel dipengaruhi bahan baku yang digunakan pada pembuatan cuka apel. Semakin banyak proporsi buah apel yang digunakan maka warna cuka apel semakin kuning hingga coklat sedangkan semakin banyak proporsi limbah apel yang digunakan akan memberikan warna putih jernih pada cuka apel. Berdasarkan hasil uji organoleptik panelis cukup tertarik pada warna kuning kecoklatan cuka apel pada perlakuan L2A2. Perbedaan warna pada cuka apel yang dihasilkan dipengaruhi oleh kandungan fenol pada buah apel dan proses pengolahan buah apel.Semakin banyak buah apel yang digunakan maka kandungan fenol pada buah apel akan semakin tinggi sehingga memicu terjadinya reaksi oksidasi fenol oleh fenoloksidase menghasilkan warna kuning kecoklat pada bahan. Menurut Zubaidah (2011) proses oksidasi pada senyawa fenol oksidase akan membentuk 
senyawa kuinon berwarna merah, coklat, hingga kehitaman. Warna akhir cuka apel inilah yang akan menentukan ketertarikan panelis terhadap warna cuka apel. Menurut SNI 01 - 4371 (1996) cuka apel memiliki warna khas cuka.

Tabel 5. Hasil Uji Organoleptik Cuka Apel

\begin{tabular}{llll}
\hline \multirow{2}{*}{ Proporsi Bahan Baku Apel } & \multicolumn{3}{l}{ Skor Nilai Organoleptik } \\
\cline { 2 - 4 } & Warna & Aroma & Kesukaan \\
\hline L0A1 $(100 \%: 0 \%-5 \%)$ & $1,7 \mathrm{a}$ & 2,2 & 2,3 \\
L0A2 $(100 \%: 0 \%-10 \%)$ & $1,6 \mathrm{a}$ & 2,0 & 2,1 \\
L0A3 $(100 \%: 0 \%-15 \%)$ & $1,8 \mathrm{a}$ & 2,1 & 2,1 \\
L1A1 $(75 \%: 25 \%-5 \%)$ & $2,0 \mathrm{~b}$ & 2,1 & 2,1 \\
L1A2 $(75 \%: 25 \%-10 \%)$ & $2,0 \mathrm{~b}$ & 2,0 & 2,3 \\
L1A3 $(75 \%: 25 \%-15 \%)$ & $2,1 \mathrm{~b}$ & 2,3 & 2,0 \\
L2A1 $(50 \%: 50 \%-5 \%)$ & $2,4 \mathrm{~b}$ & 2,4 & 2,4 \\
L2A2 $(50 \%: 50 \%-10 \%)$ & $2,7 \mathrm{~b}$ & 2,1 & 2,3 \\
L2A3 $(50 \%: 50 \%-15 \%)$ & $2,5 \mathrm{~b}$ & 2,3 & 2,3 \\
L3A1 $(25 \%: 75 \%-5 \%)$ & $2,4 \mathrm{~b}$ & 2,5 & 2,2 \\
L3A2 $(25 \%: 75 \%-10 \%)$ & $2,3 \mathrm{~b}$ & 2,6 & 2,1 \\
L3A3 $(25 \%: 75 \%-15 \%)$ & $2,4 \mathrm{~b}$ & 2,6 & 2,1 \\
\hline
\end{tabular}

Keterangan : Angka - angka yang diikuti huruf yang sama menunjukan tidak berbeda nyata menurut uji duncan pada taraf $5 \%$.

Berdasarkan hasil uji Anova menunjukan bahwa proporsi bahan baku dan konsentrasi backslop cuka apel tidak berpengaruh terhadap kadar uji organoleptik aroma pada produk cuka apel. Rata - rata aroma cuka apel pada tabel 15 menunjukan aroma cuka apel cukup menyengat khas cuka dimana nilai aroma terendah pada perlakuan L2A2 dengan penambahan proporsi bahan baku apel (50\% limbah sari apel : $50 \%$ buah apel) dan konsentrasi backslop cuka apel $10 \%$ dan nilai aroma tertinggi terdapat pada perlakuan L3A3 dengan perlakuan proporsi bahan baku cuka apel (25\% limbah sari apel : $75 \%$ buah apel) dan penambahan bakcslop cuka apel $15 \%$. Aroma pada cuka apel yang dihasilkan merupakan aroma asam asetat semakin banyak kadar asam asetat makan aroma khas menyengat asam asetat yang dihasilkan semakin terasa. Selain aroma asam asetat, asam - asam organik lainya yang terdapat pada cuka apel juga akan mempengaruhi aroma cuka apel yang dihasilkan. Menurut SNI $01-4371$ (1996) cuka apel memiliki aroma khas cuka. 
Berdasarkan hasil uji ANOVA menunjukan bahwa proporsi bahan baku dan konsentrasi backslop cuka apel tidak berpengaruh terhadap kadar uji organoleptik kesukaan pada produk cuka apel. Rerata kesukaan panelis terhadap cuka apel berdasarkan Tabel 5 menunjukan cuka apel dengan perlakuan L2A2 dengan proporsi bahan baku (50\% limbah apel : $50 \%$ buah apel) cukup disukai panelis. Perlakuan L2A2 memiliki aroma khas cuka yang tidak terlalu menyengat serta warna kuning cerah yang disukai oleh panelis. Menurut Ma'sum (2006) warna cuka apel memiliki aroma khas cuka dan warna khas cuka. Aroma pada cuka apel selain dipengaruhi oleh asam - asam organik juga dipengaruhi aroma asam malat yang terdapat pada cuka apel. Asam malat memberi aroma khas apel yang tidak dimiliki oleh buah lainya. Selain itu aroma pada cuka apel juga diakibatkan oleh aroma asam asetat yang dihasilkan selama proses fermentasi. Produk fermentasi mengakibatkan produk fermentasi memiliki rasa dan aroma yang khas. Menurut Keputusan Menteri Pertanian 893/Kpts/TP.240 (1984) buah apel mengandung kadar asam malat : 0,956 /100 g. Dalam $100 \mathrm{~g}$ ampas apel terkandung pektin sebesar $15-20 \%$ dan sisanya merupakan serat pangan (Saparianti dkk., 2009). Apel memiliki antioksidan yang lebih penting yaitu senyawaan flavonoid. Kandungan senyawaan fenolik utama pada apel segar adalah quersetin glikosida, prosianidin B2, asam klorogenat, epikatekin, dan floretin glikosida terdapat melimpah pada kulit apel, senyawa - senyawa tersebut bermanfaat bagi kesehatan tubuh dan digunakan sebagai pangan fungsional (Pietta, 2000).

Merujuk pada standar mutu cuka apel berdasarkan SNI01 - 4371 - 1996 bahwa kadar total asam cuka minimal $4 \mathrm{~g} / 100 \mathrm{ml}$, sisa alkohol maksimal $1 \% \mathrm{v} / \mathrm{v}$, padatan terlarut minimal $1 \%$ serta total gula $1 \%$ menunjukan bahwa cuka apel hasil perlakuan proporsi bahan baku dan perbedaan penambahan konsentrasi backslop cuka apel hampir mememnuhi standar SNI dan hasil organoleptik warna dan aroma memiliki karekteristik khas cuka sesuai dengan standar SNI. Perlakuan terbaik ditentukan dengan membandingkan seluruh parameter yang diukur dengan SNI 01 - 4371 - 1996. Perlakuan terbaik pada Tabel 15 terdapat pada perlakuan L3A3 dengan proporsi bahan baku (25\% limbah apel : $75 \%$ buah apel) dan penambahan konsentrasi backslop cuka apel sebesar $15 \%$ karena mengandung kadar asam asetat tertinggi $4,6 \mathrm{~g}(\mathrm{~b} / \mathrm{v})$, total padatan terlarut 4 , pH asam 3,43 dengan sisa kadar alkohol $0 \%(\mathrm{v} / \mathrm{v})$.

\section{KESIMPULAN}

Perlakuan penambahan konsentrasi pasta coklat dengan komposisi pati garut dan tepung terigu berpengaruh sangat nyata terhadap kadar air, kadar lemak, kadar protein kadar karbohidrat, tekstur, antioksidan, serta mutu organoleptik yang meliputi rasa, aroma, kesukaan dan kerenyahan cookies 
bekatul tetapi tidak berpengaruh nyata terhadap kadar abu dan uji organoleptik dalam segi kenampakan cookies bekatul tetapi terdapat beberapa parameter yang telah memenuhi syarat dari SNI 2973-2011. Perlakuan penambahan pasta cokelat dibandingkan dengan tanpa penambahan pasta cokelat menghasilkan cookies yang lebih baik dari segi kimia, fisik, dan organoleptik. Konsumen lebih menerima cookies bekatul dengan penambahan pasta cokelat. Hal ini dikarenakan rasa dan aroma berasal dari bekatul berkurang. Perlakuan komposisi pati garut : tepung terigu berpengaruh pada uji serat $1,75 \%-2,58 \%$, uji warna kekuningan $7,3 \%-10,2 \%$. Tetapi tidak berpengaruh pada hasil uji antioksidan cookies bekatul.

\section{REFERENSI}

Adzakiya MAZ. 2011. Kajian Potensi antioksidan beras merah dan pemanfaatannya pada minuman beras kencur.(Thesis).IPB.

Arifah 2013 Teknik analisis kadar amilosa dalam beras. Buletin Teknik

Astawan, M. 2004. Membuat Mie dan Bihun. Penebar Swadaya, Jakarta.

Carpenter KM, Hasin DS, Allison DB, Faith MS. 2000. Relationships betweenobesity and DSM-IV major depressive disorder, suicide ideation, and suicideattempts: results from a general population study. Am J Public Health 90, 251

Charley, H. dan Weaver C. 1998. Foods (A Scientic Approach). New Jersey : Prentice Hall Inc.

Fellows, P. J. 2000. Food Processing Technology, Principle and Practice. 2nd Ed.CRC Press, England.

Gustiar H. 2009. Sifat Fisiko-Kimia dan Indeks Glikemik Produk Cookies Berbahan Baku Pati Garut (Maranta arundinacea L) Termodifikasi. Skripsi. Fakultas Teknologi Pertanian. Institut Pertanian Bogor, Bogor.

Hodge JE dan Osman EM. 1976. Carbohydrates. Di dalam Fennema OR (ed.). Food Chemistry. Marcel Dekker Inc., New York.Honestin 2007

Karunia, Nilam. 2016. Tingkat Aktivitas Antioksidan Pada Pembuatan Kakao Massa Di Pusat Penelitian Kopi. Dan Kakao Indonesia (Puslitkoka) Jember. .Laporan Praktek Kerja Lapang. ITP: UMM

Kilcast, D. (Ed), 2004. Texture in Food Volume 2: Solid Foods. Woodhead Publishing Limited, England.

Kosasih E.N, dkk. 2004. Peran Antioksidan pada Lanjut Usia. Jakarta : Pusat Kajian Nasional Masalah Lansia.

Muchtadi D, Astawan M, dan Palupi NS. 2006. Metabolisme Zat Gizi Pangan. Jakarta: Universitas Terbuka.

Permana, dan Widya. 2015. Karakteristik Fisik Kimia Flakes Jagung dan Kacang Merah. Jurnal Pangan dan Agroindustri Vol. 3 No 2 p.734-742 Universitas Brawijaya Malang. Malang

Riyadi, Lieke. 2007. Teknologi Fermentasi. Yogyakarta: Graha Ilmu.

Rokhmawati, D. 2006. Pengolahan Biskuit Berbahan Baku Tepung Pisang (Kajian Varietas Pisang dan Komposisi Tepung Pisang : Tepung Terigu). Skripsi. Fakultas Pertanian. Universitas Muhammadiyah Malang, Malang. 
Sudarmadji, Slamet, 2003. Analisa Bahan Makanan dan Pertanian. Penerbit Liberty. Yogyakarta.

Suntoso, T, Budi. 2011. Teknologi Pengolahan Hasil Pertanian. PT Bina Ilmu: Surabaya Swastika, 2009

Wahyudi, M. 2006. Proses Pembuatan dan Analisis Mutu Yoghurt. Buletin Teknik Pertanian. Vol. 11 No. 1

Winarno, F.G. 2008. Kimia Pangan dan Gizi. Gramedia Pustaka Utama, Jakarta. 